\title{
현대 국제분쟁의 유형과 성격: \\ 분쟁과 개발의 관점에서
}

목 차

I. 들어가며

II. 낡은 전쟁과 새로운 전쟁: 폭력의 국가 독점에서 (재)사유화로

1. 클라우제비츠의 전쟁론: 국가와 합법적 폭력의 독점

2. 새로운 전쟁(?): 국가의 후퇴와 비국가 행위자들, 그리고 폭력의 (재)사유화

III. 새로운 전쟁에 대한 국제사회의 대응 방식: 의의와 한계

1. 국제정치적 및 군사적 측면

2. 법·제도 및 국제개발협력의 측면

IV. 나오며: 하나의 논리로 통합돼 가는 '안보'와 '개발'

\section{I. 들어가며}

1989년 11월 9일(목), 서독과 동독의 자유로운 왕래가 허용되면서 냉전의 상징이던 베를린 장벽이 붕괴한 지 25년이 지난 지금 국제사회는 다시 '신냉전' 또는 '냉전의 귀환'을 이야기하고 있다. 유럽에서는 유럽연합 가입을 놓고 국론이 분열돼 국토가 가입을 지지하는 서쪽과 이에 반대하는 친-러시아 성향의 동쪽으로 갈린 우크라이나 를 사이에 두고 각각 서방과 러시아가 정치·경제·군사적으로 대치하고 있고1), 동북아 시아에서는 중국의 정치적·경제적 부상에 맞서 미국을 등에 업은 일본이 애초 전쟁을

1) International Crisis Group. 2014(a). "Ukraine: Running out of Time”. Europe Report No 231. Belgium: Brussels을 볼 것. 
금지하고 있는 평화헌법에 대해 집단적 자위권이 가능하다는 '해석 개헌'을 통해 전 쟁을 할 수 있는 나라로 탈바꿈함으로써 중국과 미·일 사이에 (신)냉전의 기류가 흐 르고 있다. ${ }^{2}$ 탈냉전 이후 우리의 기억에서 희미해져 가던 국가 간 총력전을 함의하 는 양차대전의 '세계전쟁' 또는 핵무기 개발 등 군비경쟁으로 치달았던 냉전의 공포 가 다시 고개를 내밀고 있는 것은 아닌지 우려스럽다.

물론 이런 세계전쟁의 공포에 앞서 현재 세계 곳곳에서는 분쟁이 끊이지 않고 있다. 몇 가지 예를 나열하면, 2001년 9/11 테러 이후 미국의 대테러리즘(anti-terrorism)의 일환으로 그해 10월 7일(일) 시작해 13년째 전쟁을 치르고 있는 아프가니스탄, 2011년 아랍의 봄 당시 반정부 투쟁이 발생해 3 년 반 넘게 내전을 치르고 있는 시리아, 최근 이슬람국가Islamic State(IS)라는 강경 수니파 이슬람 근본주의 무장 단체의 등장으로 거의 내전 상황이나 다름없는 이라크, 이외에도 우크라이나를 비롯해 파키스탄, 말리, 나이지리아, 콩고민주공화국, 중앙아프리카공화국, (남)수단, 케냐, 소말리아 등이 탈 냉전 국면에서 인종이나 종족, 언어와 문화, 종교 등이 얽히고설킨 분쟁 및 테러리즘 으로 몸살을 않고 있다.

그런데 이런 분쟁은 기존에 인류가 경험한 양차대전이나 냉전 시기에 일어난 분쟁 과 한 가지 다른 특징이 있다. 근대국가의 출현 이후 냉전 시기까지의 전쟁이 '국가 간(inter-state)'의 전면전을 특징으로 했다면, 냉전 이후에는 소위 내전(civil war) 으로 불리는 '국가 내부(within state or intrastate)' 행위자들 간의 싸움, 즉 무장 투쟁(armed conflicts)이 주요 특징이다. 이런 무장투쟁은 냉전 시절에 이데올로기에 억눌렸던 인종이나 종족, 언어와 문화, 종교 간의 이질성이 분쟁의 주요 원인으로 작 동하면서 서로 다른 이질적인 집단 사이에 대량학살과 인종청소 - 예를 들어, 1990 년대 이후 발생한 유고슬라비아 전쟁, 르완다와 콩고 내전, 동티모르 내전, 그리고 최근 기독교계와 이슬람계의 갈등이 재발한 중앙아프리카공화국 등 - 라는 충격적인 반인도적 범죄를 양산했고, 최근에는 여기에 테러리즘이 가세하면서 분쟁이 장기화 하고 영속화하는 경향이 나타나고 있다. 시기를 특정 하는 것이 다소 무리가 있을 수 있지만 논리의 편의상 구분하면, 냉전과 탈냉전을 기점으로 국제 분쟁의 주요 양 상이 ‘국가 간 전쟁’에서 ‘국가 내부 분쟁’으로 바뀌었다고 할 수 있다.

2) International Crisis Group. 2014(b). "Old Scores and New Grudges: Evolving Sino-Japanese Tensions". Asia Report No 258. Belgium: Brussels를 볼 것. 
그런데 탈냉전 국면에서 일어난 이런 국제분쟁의 양상 변화는 국제안보 측면에서 한 가지 큰 함의를 갖는다. 그것은 분쟁이 주로 국가 내부에서 발생하지만 실제로 미 치는 영향은 국경을 넘어선다는 것이다. 기존 국가 간 전쟁은 국가안보를 이유로 국 경 수호를 최우선으로 했는데, 탈냉전 국면에서 벌어지고 있는 국제 분쟁은 국경을 초월해 국제질서를 해치면서 국가안보를 이유로 국경을 수호하는 것이 다소 무색해졌 다. 분쟁으로 인한 대규모 난민 및 이민 물결, 2001년 9/11 테러 이후 일상화 돼 전 세계를 공포로 몰아넣은 테러리즘이 대표적이다. 물론 이 때문에 선진국들의 경우 국 경 검문이나 공항 및 항만의 수속 절차를 강화했지만, 어느 한 지역의 분쟁이 국제안 보를 헤치는 것은 세계화한 세계에서 이미 거스를 수 없는 주요 현상이 됐다. 국경을 초월하는 안보 이슈는 이것만이 아니다. 최근 서아프리카에서 발병해 전 세계를 바이 러스의 공포로 몰아넣은 에볼라 사태가 단적인 예다. ${ }^{3)}$ 그리고 많은 전문가들이 향후 국제질서를 크게 위협할 주요 요소로 꼽는 물 부족이나 식량 부족 사태, 다시 말해 기후변화에 따른 환경재앙 역시 국경을 초월하는 안보 이슈다. ${ }^{4)}$ 요약하면, 냉전 시절 의 국가 간 전쟁이 국가안보를 위협했다면, 초월적 성격을 띠는 탈냉전 시기의 분쟁 은 인간안보(human security)5), 즉 잠재적으로 인류 모두의 안보를 위협한다.

3) 지난 9월18일(목), 유엔안전보장이사회(이하 유엔안보리 또는 안보리)는 에볼라를 세계 평화와 안보를 해치는 주요 원인으로 간주하고 이를 퇴치하기 위한 결의안을 채택했 다. 유엔안보리가 국제 보건과 관련해 결의안을 채택한 것은 2000년과 2011년에 에이 즈 확산 방지 관련 결의안 채택 이후 세 번째다. 이에 대해서는 http://www.un.org/press/en/2014/sc11566.doc.htm를 볼 것. (검색일: 2014.9.30)

4) 세계은행 김용 총재는 지난 4월 초 영국의 주요 일간지 <가디언>과의 인터뷰에서 향후 10년 이내에 물과 식량을 둘러싼 전쟁이 일어날 수 있다고 경고했다. 이에 대해서는 http://www.theguardian.com/environment/2014/apr/03/climate-change-battle-food -head-world-bank를 볼 것. (검색일: 2014.11.3) 한편, 세계경제포럼은 기후변화 외 에도 금융위기, 거버넌스 실패, 실업, 소득 불평등을 향후 세계질서를 위협할 10대 위 험 요소에 포함했다. 이에 대해서는 World Economic Forum. 2014. Global Risks 2014(9th Edition). Geneva: World Economic Forum, p. 9.

5) 인간안보라는 개념이 처음 등장하는 곳은 유엔개발계획United Nations Development Plans(UNDP)이 1994년에 발간한 <인간개발보고서 Human Development Report>다. 이후 국제안보에서 인간안보가 널리 차용됐는데, <인간개발보고서>에서 사용한 인간안 보가 인간개발human development이라는 좀 더 광범위한 차원, 즉 억압과 배고픔, 질 병에서의 자유로 정의된다면, 국제정치나 국제안보에서 사용되는 인간안보는 좁게는 무 력 사용, 넓게는 초월적인 안보 위협에 따른 인간 개개인의 생존 위협, 즉 공포로부터의 자유에 한정하는 경향이 있다. 이에 대해서는 United Nations Development Programme. 1994. Human Development Report 1994. Oxford: Oxford University Press와 Pauline Kerr. 2010. "Human Security", Alan Collins ed. Contemporary Security Studies(2nd Edition). Oxford: Oxford University Press. pp. 121-135를 볼 것. 
이 논문은 1980 년대 말 냉전 종식 이후 나타난 새로운 분쟁의 유형과 그것의 원인 및 성격을 분석하는데 목적이 있다. 그리고 이런 새로운 분쟁에 대해 국제사회가 어 떤 식으로 대응하고 있는지 국제정치적 맥락과 국제개발협력의 맥락에서 각각 살펴 보고, 그 의미와 한계를 짚어보고자 한다.

\section{II. 낡은 전쟁과 새로운 전쟁: 폭력의 국가 독점에서 (재)사유화로}

\section{1. 클라우제비츠의 전쟁론: 국가와 합법적 폭력의 독점}

현대 전쟁뿐만 아니라 역사를 막론하고 전쟁을 이야기할 때 빼놓을 수 없는 인물 이 있다. 바로 카를 폰 클라우제비츠(Carl von Clausewitz, 1780.6.1 1831.11.16) 다. 1780 년에 프로이센에서 태어난 클라우제비츠는 프랑스혁명과 나폴레옹전쟁에 참 전했던 군인이자 군사 전략가이자 사상가다. 나폴레옹전쟁이 끝난 1816 년에 집필하 기 시작해 그의 사후에 유고집으로 출간한 〈전쟁론 On War〉(1832)에서 그는 전쟁을 '상대에게 우리의 의지를 강제하기 위한 폭력행위', 나아가 '전쟁은 또 다른 수단을 통한 정치의 연장'(각각 Clausewitz 1832, p. 101; 99)이라는 유명한 말을 남겼다. 이는 전쟁을 전투 그 자체보다는 정치적 목적을 달성하기 위한 하나의 수단으로 해 석한 것으로 근대국가에서 국가가 수행하는 전쟁을 '합리화'하는 이론적 토대를 제공 했다. ${ }^{6)}$

여기에서 클라우제비츠를 거론하는 것은 그의 '전쟁론'을 소개하거나 그의 이론이 지금도 현실적실성을 갖고 있다고 주장하기 위해서가 아니라 그의 전쟁론의 핵심이 전쟁 수행 주체로서 국가를 핵심 분석 대상으로 하기 때문이다. ${ }^{7)}$ 그의 전쟁론 또는 ‘전쟁 수행 주체로서 국가'는 근대국가의 등장과 발전뿐만 아니라 탈냉전 이후 전쟁

6) 클라우제비츠가 전쟁을 국가의 정당한 정치 및 정책 수행 수단으로 합리화한 것에 대 해 비판이 없는 것은 아니다. 영국의 전쟁사학자 존 키건John Keegan은 그의 저서 <전쟁의 역사 History of Warfare>(1994)에서 국가는 국민의 안전과 행복을 도모해야 하는 데 전쟁이 그 반대라고 할 경우 어떻게 합리화할 수 있느냐고 반문한다.

7) 클라우제비츠는 전쟁을 국가, 군인, 국민의 삼위일체로 정의한다. 이를 통해 하나의 이 념형 또는 추상이라고 할 수 있는 '절대전쟁'을 이끌어 내고 이것을 현실의 전쟁과 비 교하며 자신의 <전쟁론>을 전개한다. 전쟁은 속성상 극단으로 치닫는 경향이 있지만, 현실의 여러 제약 요인에서 자유로울 수 없다는 주장이다. 
수행 주체가 국가 중심에서 비국가 행위자로 다양화하는 현상을 이해하는 데 있어 중요하다.

클라우제비츠가 주장한 전쟁론 또는 이어서 파생한 근대 전쟁론의 핵심을 두 가지 로 요약하면 다음과 같다. 하나는 전쟁 수행 주체로서 일정한 영토를 기반으로 '폭력 을 독점'하는 국가이고, 다른 하나는 이런 폭력 독점을 합리화하기 위한 법·제도 장치 의 도입과 이데올로기의 동원이다. 중세에서 근대로 넘어오면서 국가는 거의 모든 권력을 중앙집권화 한다. 입법, 사법, 행정은 물론 군대를 독점했다. 중세에 영주와 기사, 강도, 산적, 해적 등이 사유화했던 폭력이 전면 금지되고 이 모든 것이 국가의 수중으로 넘어갔다. 특히 근대국가가 군대를 독점할 수 있었던 것은 바로 용병제를 대체한 직업군인 중심의 상비군 창설 덕분이었다. 그리고 이에 따라 상비군 유지에 필요한 재정을 마련하기 위한 조세(taxation) 권한 역시 근대국가의 전유물이 됐다.

그런데 근대국가의 폭력 독점이 자연스럽게 이뤄진 것은 아니다. 이는 근대국가의 폭력 독점 과정에 저항이나 또 다른 의미의 폭력 — 국가의 폭력 독점에 저항하는 세 력들에 대한 억압 - 이 없었다는 뜻이 아니라 이를 정당화하기 위한 여러 가지 법. 제도적 장치와 이데올로기적 기제가 동시에 사용됐다는 뜻이다. 이는 근대국가가 폭 력을 배타적으로 소유하고 사용하기 위해서는 당연했다. 우선, 국가의 폭력 독점과 사용을 정당화하기 위해 도입된 수사가 '국익(national interests)'이다. 중세시기에 전쟁은 종교적 목적을 우선시했기 때문에 이를 정당화하는 것은 신성 또는 교황의 권위였다. 그러나 근대국가에서 전쟁은 당시 국제질서에서 필수불가결하다는 인식이 자리 잡으면서 철저히 현실적인 국익 - 영토의 확장, 교역 안정, 영토 수호, 국민안 전 - 을 앞세웠다(김재천 2008, p. 4). 즉, 전투 수행의 정당성이 성스러운 것에서 세속적인 것으로 바뀐 것이다. 이에 따라 전쟁 수행에 대한 여러 가지 '세속적' 규칙 을 포함한 법·제도적 장치들이 마련됐다.

네덜란드 태생으로 이스라엘의 군사 역사학자이자 이론가인 마틴 반 크레벨트 (Martin van Creveld)에 따르면 근대국가가 폭력을 독점하게 되면서 전쟁과 단순 범죄를 구별하기 위해 전쟁은 주권국가만이 벌일 수 있는 어떤 것으로 정의됐고, 병 사와 민간인 또는 범죄자를 구별하는 제복이 도입되면서 철저한 복무규정8)이 제정됐 
으며, 전쟁개시나 휴전협정, 전쟁 포로에 대한 규정을 포함해 전투상황 뿐만 아니라 비전투 상황에서 철저한 민간인 보호 등의 규칙이 만들어졌다고 한다(Creveld 1991, p. 7). 근대국가의 폭력 독점을 합리화하는 이런 법·제도적 장치들은 19 세기와 20 세 기 들어 국가 간 전쟁이 다반사로 일어나면서 국제규범 및 규칙으로 발전해 나갔다. 1863년 남북전쟁 당시 에이브러햄 링컨(Abraham Lincoln)의 지시로 작성된 지상전 개전 규칙과 점령지 노예 및 포로에 대한 규정을 담은 리버훈령(Lieber Cord)9), 1864년 전쟁 중 부상자를 시작으로 민간인, 전쟁포로, 부상병 및 병든 군인에 대한 처우를 차례로 규정한 제네바협약(Geneva Conventions), 전쟁에서 독가스와 세균 사용 을 금지한 1925년의 제네바의정서(Geneva Protocol), 제2차 세계대전 직후 전쟁 범죄를 단죄하기 위해 설립한 국제사법재판소(International Criminal Court(ICC)), 1967년에 미·소가 합의한 핵 확산 금지 조약, 1993 년에 발효한 화학무기의 개발, 생산, 비축, 사용 을 금지하고 폐기에 관한 내용을 담은 화학무기금지조약(Chemical Weapons Convention(CWC)), 2003년에 도입한 대량살상무기 확산방지구상(Weapons of Mass Destruction Proliferation Security Initiative) 등이 폭력을 독점한 국가의 전쟁 수행 을 합리화하고, 반대로 비국가 행위자들의 폭력 사용을 금지하고 불법화하는 법·제도적 근거가 됐다.

국가의 폭력 독점과 전쟁 수행을 합리화하는데 여러 이데올로기도 동원됐다. 국가 간 전쟁이 국가의 인적, 물적 자원이 총 동원되는 총력전 양상으로 전개되면서 국가 의 사활이 걸린 문제가 되자 전쟁을 합리화하면서 국민을 동원하고 지지를 이끌어내 기 위해 다양한 이데올로기가 사용됐다. 역사적으로 전쟁을 미화하는 데 동원된 문 명과 야만, 영웅주의, 애국심, 선악의 이원론이 노골적으로 동원됐다. 보통 전쟁에 대중을 동원하기 위해 이데올로기적 선전, 선동 기법을 최초로 또 광범위하게 사용 한 것은 독일의 나치였지만, 이후 거의 모든 나라들에서 이는, 비록 형식이나 내용은 조금씩 달랐지만, 보편적인 것이 됐다. 요약하면, 중세에서 근대로 넘어오면서 형성 된 '합법적으로 폭력을 독점하는 국가' 그리고 이에 근거한 국가 간 전쟁은 20 세기

8) 병사에 대한 대표적인 복무규정으로는 제복을 입었을 때만 전투를 할 수 있고, 상관의 명령에 대해 철저히 복종하며, 노략질을 하지 않는다, 등이 있다(Creveld 1991, p. 7).

9) 독일 법학자 프란츠 리버Franz Lieber(1789.3.18 1872.10.2)의 이름을 딴 것으로 남 북전쟁 당시 링컨의 지시로 작성돼 지상전 규칙과 점령지 노예 및 전쟁 포로에 대한 처우 및 대우를 엄격하게 규정하고 있다. 
전반에 일어난 양차대전 이후 냉전 기간 동안 국가 간 전쟁이 각각 자본주의와 공산 주의를 앞세운 미국과 소련을 축으로 한 진영 논리와 핵무기라는 가공할 파괴력 앞 에서 억눌리기는 했지만 냉전이 종식하기까지 국제전쟁의 두드러진 양상이었다.

\section{2. 새로운 전쟁(?): 국가의 후퇴와 비국가 행위자들, 그리고 폭력의 (재)사유화}

그런데 냉전이 종식하면서 전쟁의 양상에도 두드러진 변화가 일어났다. 유럽의 구 (舊)유고슬라비아 내전을 비롯해 아프리카의 알제리, 르완다, 콩고, 수단, 소말리아 내전, 아시아의 동티모르 분쟁 등 세계 도처에서 인종이나 종족, 종파가 결부한 민족 분쟁이 일어났다. 앞서 지적한 대로 냉전과 탈냉전으로 시기를 구분하는 것이 논리 상 편의에 따른 것이지만, 확실한 것은 탈냉전 국면에서 국가 간 전쟁은 줄어든 대 신 보통 내전으로 불리는 국가 내부의 분쟁이 증가했다는 사실이다. 다시 말해, 냉전 이전에 국제관계에서 전쟁의 주체가 주로 국가였다면, 탈냉전 국면에서 국가가 아닌, 다시 말해 비국가 행위자라고 할 수 있는 인종, 종족, 종파를 배경으로 하는 무장세 력들(armed groups)이 전쟁의 당사자로 국제사회의 전면에 등장했다. 이런 현상은 1989년 베를린 장벽으로 냉전이 붕괴한지 25년이 지난 지금까지도 진행 중인 현상이 다. 여기서 한 가지 분명히 하고 넘어가고 싶은 것은 '국가 간 전쟁'과 '국가 내부 전 쟁’이 냉전과 탈냉전 국면의 전쟁 양상을 구분하는 절대적인 기준은 아니라는 것이 다. ${ }^{10)}$ 냉전 시절에도 국가 내부 분쟁이 상존했다. 군부쿠데타, 게릴라전쟁, 저강도전 쟁(low-intensity conflict)11) 등이 있었고, 냉전 종식 이후에 더욱 두드러진 현상이 기는 하지만 이념, 인종이나 종족, 종파를 배경으로 한 내전이 발생해 탈냉전 이후인 지금까지도 존속하는 경우가 있다. 예를 들어, 아프가니스탄 내전과 이스라엘-팔레 스타인 분쟁이 대표적인 사례다. 반대로 탈냉전 국면에서도 국가 간 전쟁이 일어났 다. 냉전이 종식한 해인 1989년 12월 발생한 미국의 파나마 침공, 이듬해인 1990년 에 일어난 이라크의 쿠웨이트 침공, 1994 년 러시아의 체첸 침공, 2003 년 미국의 이

10) 이에 대해서는 Colin M. Fleming. 2009. "New or Old Wars? Debating a Clausewitzian Future". The Journal of Strategic Studies Vol. 32 No. 2. pp. 213-241.

11) 저강도전쟁이란 미국이 1970년대와 1980년대 제3세계를 상대로 펼쳤던 일종의 정치. 군사 전략으로 특수부대를 이용하거나 반군 단체를 지원함으로써 정치체제를 바꾸는 전략이었다. 1970년대 칠레 아옌데 정권의 붕괴, 1980년대 니카라과의 산디니스타 혁 명 정부를 전복하기 위해 친미 성향의 '콘트라 반군'을 지원한 것이 대표적인 사례다. 
라크 침공, 2008년 러시아-그루지아 전쟁 등이 대표적이다. 다시 말해, 국가 간 전 쟁과 국가 내부 분쟁은 냉전과 탈냉전을 가로 질러 연속성을 갖는 현상으로 다만 냉 전 시절에는 국가 간 전쟁이, 탈냉전 국면에는 국가 내부 분쟁이 더 두드러진다.

냉전 종식을 이데올로기의 종언으로 또는 사회주의에 대한 자유주의의 최종 승리 로 단언했던 미국의 정치경제학자 프란시스 후쿠야마(Francis Fukuyama)의 〈역사의 종언 The End of History and the Last Man>(1992)을 비웃기라도 하듯 우후죽순 처럼 일어난 비국가 행위자들 간의 분쟁에 대해 영국 런던정경대학교 글로벌 거버넌 스 교수인 매리 캘도어(Mary Kaldor)는 기존의 국가 간 전쟁을 지칭하는 '낡은 전쟁 (old wars)'에 빗대어 '새로운 전쟁(new wars)'이라고 부른다. 12) 캘도어는 '새로운 전쟁'은 '낡은 전쟁’과 비교해 전쟁의 목표와 전투 방식, 재정 조달 방식에서 크게 다 르다고 주장한다(Kaldor 2006). 그녀의 주장을 요약하면 다음과 같다. 첫째, 전쟁의 목표가 근대 전쟁의 특징이었던 영토 점령이나 냉전 시기의 주요 특징인 이데올로기 대결이 아닌 정체성 투쟁, 즉 인정 투쟁을 목표로 한다. 탈냉전 국면에서 일어난 분 쟁은 대다수가 인종이나 종족, 언어와 문화, 종교에 바탕을 두고 있다. 다시 말해, 새로운 전쟁은 정체성이 다른 집단 또는 냉전 시절 이데올로기와 영토적 국가 중심 성에 억눌려 있거나 사로잡혀 있었던 집단이 폭력적인 방식으로 자신의 고유한 정체 성을 되찾거나 인정받고자 하는 행위와 관련이 있다. 캘도어는 이런 현상이 나타난 원인을 탈냉전 국면에서 유행처럼 번진 세계화(globalisation)와 그 결과로 나타난 국가주권의 약화에서 찾는다. 세계화가 정보통신의 급속한 발전에 힘입어 정치, 경 제, 사회, 문화 등 거의 모든 분야에서 세계가 국경을 초월해 하나로 연결 되어가는 것을 함의한다고 할 경우, 이런 정체성 정치의 등장은 세계화의 흐름에 역행하는 것

12) 참고로 미국의 군사전문가 윌리엄 S. 린드(William S. Lind)는 탈냉전 이후 등장한 전 쟁 유형을 제4세대 전쟁으로 정의한다. 제 1 세대 전쟁은 1648년 베스트팔렌조약 이후 국가가 폭력을 독점하면서 나타난 전쟁 유형으로 활강식 소총을 사용하는 병력 위주 의 전쟁으로 전투원과 민간인의 구분이 뚜렷해졌고, 제 2 세대 전쟁은 제 1 차 세계대전 기간에 등장한 강선식 소총과 포, 기관총 등 대규모 화력 위주의 전쟁, 제3세대 전쟁 은 제 1 차 세계대전 이후 등장한 전쟁 양상으로 제2차 세계대전 당시 독일군이 활용한 기동전을 특징으로 한다. 제4세대 전쟁은 정치, 경제, 사회, 군사적 요소가 모두 동원 되는 최근의 전쟁 양상으로, 제 1 세대에서 제 3 세대까지의 전쟁이 국가 대 국가의 대결 양상이었다면 제4세대 전쟁은 비국가 행위자가 국가를 상대로 소규모 전쟁이나 심리 전을 수행할 수 있는 형식의 전쟁이다. 이에 대해서는 William S. Lind. 2004. "Understanding Fourth Generation War", Military Review 83/5(Sept.-Oct.)를 볼 것. 
이다. 그런데 이런 정체성 정치의 등장은 사실 세계화의 결과물이라고 할 수 있다. 국가와 영토, 이념의 장벽이 사라진 세계에서 개개인은 자신이 속한 인종이나 종족, 언어와 문화, 종교는 물론 이를 초월해 세계 각지의 다른 사람과 교류하며 관심이나 성향에 따라 다양한 정체성을 만들어가고 있다. 바로 정보통신의 발달과 네트워크화 덕분이다. 여하튼, 이런 정체성 정치의 등장은 세계화의 주요 흐름이라고 할 수 있는 획일화나 일반화를 거스르는 현상으로 '세계화의 역설(paradox of globalisation)'이 라고 할 수 있을 것이다.

둘째, 전투 방식 또는 폭력 양상의 변화다. 새로운 전쟁은 국가 간 전쟁과는 다르 게 정체성이 다른 비국가 행위자들이 서로에 대해 공포와 증오를 키우다가 결국 극 단주의로 치닫는 경향이 있다. 비록 과거 국가 간 전쟁에서 극단주의나 인종청소 같 은 대량학살이 없었던 것은 아니지만, 탈냉전 국면에서 일어난 새로운 전쟁은 대개 인종청소와 같은 대량학살을 비롯해, 강간, 납치, 인신매매 같은 비인도적인 범죄를 수반한다. 새로운 전쟁의 이런 경향은 기존에 합법적으로 폭력을 독점했던 주권국가 의 약화로 인해 비국가 행위자들이 폭력을 (재)사유화하고, 근대국가의 전쟁이 전투 원과 민간인을 엄격히 구분했던 것과 달리 이런 구분이 불분명해졌기 때문이다. 이 로 인해 전투원보다 민간인 피해가 급증하고 있는데, 캘도어에 따르면 20세기 전환 기에 일어난 전쟁에서 군인과 민간인 사망자의 비율이 8:1이었다면, 1990년대 벌어 진 전쟁에서는 이 비율이 $1: 8$ 로 정확히 역전됐다고 한다(Kaldor 2006, p. 9). 다시 말해, 국가의 폭력 독점을 합리화하는 수단이자 국가 간 전쟁이 극단으로 치닫는 것 을 규제했던 전쟁 관련 국제규범 및 규칙이 와해 내지 무의미해진 것으로 전투 방식 만 놓고 보면 오히려 전근대적인 것으로 퇴행한 것처럼 보인다.

마지막 특징은 전쟁을 계속 수행하기 위해 필요한 재정 조달 방식의 변화다. 앞서 다룬 대로 근대국가에서 전쟁 재정의 조달은 중앙집권적이었다. 하지만 새로운 전쟁 은 비국가 행위자들이 전투를 수행하는 만큼 분산적일 수밖에 없다. 그런데다가 전 쟁이 국내에서 주로 발생하는 만큼 생산에 부정적인 영향을 초래해 필요한 자금을 확보하는 것이 쉽지 않다. 이 때문에 약탈과 인질 납치, 마약 밀매, 원유나 천연자원 밀매, 다이아몬드 등 귀금속의 암거래, 또는 외부 원조를 통해 자금을 조달한다. 외 부 원조로는 국외 이주자들이 보내는 송금과 인도주의 원조에 대한 '과세' 등이 있는 
데, 문제는 이런 자금 확보 방식이 폭력과 혼란이 계속돼야 유지할 수 있는 것으로 전쟁과 경제의 작동 원리가 밀접히 결합한다는 것이다. 영국 옥스퍼드대학교 경제학 과 교수인 폴 콜리어(Paul Collier)가 '분쟁의 덫(trap of conflict)'이라고 표현한 바 로 그런 상황이다(Collier 2007). 이런 현상은 2001년 9/11 테러 이후 테러리즘이 전 지구적으로 확산하면서 더욱 가중하고 있다. 현재 중동과 북아프리카를 중심으로 테 러 활동을 벌이고 있는 테러 단체들은 분쟁 국가나 지역을 거점으로 세력을 확산하 면서 분쟁을 부추기는 것은 물론 영속화하고 있다. 특히 분쟁을 틈타 약탈과 인질 납치, 밀매, 해외 원조자금 갈취 등 각종 범죄를 일삼고 있는데, 일부 전투 집단이나 테러 단체의 경우 범죄 집단과 구분이 되지 않을 정도로 '조직화한 범죄(organized crimes')를 저지르고 있다.

캘도어가 주장하는 새로운 전쟁의 세 가지 특징이 함의하는 것을 요약하면 새로운 전쟁은 과거 국가가 합법적으로 독점했던 폭력이 전투 집단에 의해 (재)사유화되면서 폭력 사용이 불법적으로 이뤄지고, 이 결과 민간인과 전투원 간의 구분이 모호해지 면서 민간인을 대상으로 하는 비인도적 행위가 만연하고 있고, 또 이로 인해 기존에 국가안보 또는 국민안보의 최종 보루였던 국가가 경우에 따라 자국민의 안전을 해치 는 당사자가 되면서 국가가 비전투 행위자들과 크게 다를 것이 없어졌으며, 나아가 분쟁 상황을 틈타 각종 범죄가 난무하면서 전투 집단과 범죄 집단이 구분되지 않는 특성이 있다. 이런 새로운 전쟁은 과거 국경을 중심으로 국가안보를 중시했던 국가 간 전쟁과 달리 그 파급효과가 국경을 초월해 이웃 국가나 다른 지역에까지 미치면 서 인간안보, 즉 선진국과 개도국 구분 없이 지구상에 살아가는 모든 개개인의 안전 과 행복을 헤치는 경향이 나타나고 있다.

\section{III. '새로운 전쟁' 에 대한 국제사회의 대응 방식: 의미와 한계}

그렇다면 새로운 전쟁에 대한 국제사회의 대응 방식은 어떨까. 냉전 종식 이후 과 거 동구권 국가들을 포함해 아프리카와 중동 국가들에서 인종이나 종족, 언어, 문화, 종교, 그리고 여기에 테러리즘이 가세한 분쟁이 일어나자 국제사회는 유엔, 특히 안 보리를 중심으로 이를 해결하고, 평화를 구축하고, 또 분쟁에서 벗어난 국가들의 재 건을 돕기 위해 노력을 많이 해왔다. 이 밖에도 유럽연합 European Union(EU), 아 
프리카연합 African Union(AU), 미주기구 Organization of American States(OAS) 등의 지역기구, 북대서양조약기구 North Atlantic Treaty Organisation(이하 NATO), 유럽안보협력기구 Organisation for Security and Co-operation in Europe(OSCE), 상하이협력기구 Shanghai Cooperation Organisation(SCO) 같은 안보협력체, 뿐만 세 계은행 World Bank(WB)과 국제통화기금 International Monetary Fund(IMF), 아시 아개발은행 Asia Development Bank(ADB) 등 다자기구들도 분쟁 해결을 위해 적극 나서고 있다. 이런 국제사회의 노력은 접근 경로에 따라 크게 두 가지로 나눠볼 수 있 다. 하나는 국제정치적 및 군사적 측면이고, 다른 하나는 법.제도 및 국제개발협력의 측면이다.

\section{1. 국제정치적 및 군사적 측면}

\section{1) 인도주의적 개입과 보호책임}

탈냉전 국면에서 일어난 분쟁이 대량학살과 인종청소, 대규모 난민 발생, 기타 인 권침해 등 인도주의의 문제를 야기하자 국제사회, 특히 유엔과 서방 선진국을 중심 으로 인도적 지원, 분쟁해결, 평화강제(peace enforcement)를 이유로 정치적으로 또 는 군사적으로 개입했다. 이를 인도주의적 개입(humanitarian intervention)이라고 하는데 대표적인 사례가 1992년에 미국의 소말리아 개입과 1999년에 NATO의 코소 보 개입이다. 전자는 유엔의 위임을 받아 미국이 다국적군을 조직해 개입한 사례이 고, 후자는 유엔의 승인 없이 NATO가 일방적으로 개입한 사례다. ${ }^{13)}$ 미국의 소말리 아 개입은 1991년 소말리아에서 군부 쿠데타로 정권이 붕괴한 후 군벌들이 난립하는 등 내전이 발생해 대규모 민간인 사상자와 난민이 발생하고 기근이 심각하자 인도적 지원, 특히 구호물자의 안전한 운송과 배급을 목적으로 취해졌다. 하지만 1993년에 수도 모가디슈에서 일어난 전투에 파병한 미군 특수부대원을 태운 헬기 두 대가 격 추당해 전원 사망하고, 조종사로 밝혀진 시신이 군중에 의해 질질 끌려 다니는 장면 이 방송으로 보도되자 미국 내 여론이 악화하면서 결국 후속 대책 없이 철군했다.

13) 냉전 시기에 일어난 인도주의적 개입 사례로는 유엔의 콩고 개입(1964), 미국의 도미 니카공화국 개입(1965), 인도의 동파키스탄 개입(1971), 베트남의 캄보디아 개입 (1978), 그리고 우간다-탄자니아 전쟁(1979)이 있다. 
이후에도 내전이 지속돼 현재 소말리아는 거의 무정부 상태로 전락해 국가 기능이 작동하지 않는 실패한 국가(failed state)의 대명사가 됐다(최의철 $2003, \mathrm{pp}$. $392-393) .{ }^{14}$

코소보는 구 유고연방 - 보스니아-헤르체고비나, 슬로베니아, 크로아티아, 세르 비아, 몬테네그로, 마케도니아 — 의 자치주이며, 알바니아계 무슬림이 약 $88 \%$ 로 인 구의 다수를 차지한다. 1980년대 말 공산권 붕괴로 구 유고연방이 해체된 뒤 코소보 의 알바니아계 무슬림이 분리 독립을 요구했다. 당시 코소보는 세르비아계 - 그리스 정교의 일파인 세르비아정교 - 가 정권을 잡고 있던 신 유고연방 - 2006년에 최종 분리 독립한 세르비아와 몬테네그로 연방 - 의 지배를 받으면서 인종적으로나 종교 적으로 차별을 받았다. 그러던 중 1998년 2월, 코소보를 순찰하던 세르비아계 경찰 관 네 명이 알바니아계 민병대에 의해 살해되는 사건을 계기로 급기야 교전이 발생 해 끝내 인종 분쟁으로 치달았다. NATO는 세르비아계가 알바니아계를 무참히 학살 하고 이 때 발생한 난민이 서유럽으로 몰려오자 '인도주의 개입'을 명분으로 안보리 의 승인 없이 단독으로 세르비아를 공습했다.

이상의 두 사례는 인도주의 개입의 역사에서 두 가지 역설적 함의를 갖는다. 우선, 미국의 소말리아 개입은, 비록 소말리아의 대규모 인도주의 위기 상황에서 이를 지 원한다는 명분이 있었지만, 미국이 지정학적으로나 경제적으로 별다른 이해관계가 없는 곳에서 자국 군인이 사망하고 이에 대한 국내 비난 여론이 들끓으면서 철수한 사건으로 강대국 주도의 '순수한' 인도주의 개입이 결국은 국익에 좌우된다고 하는 부정적인 인식을 낳았다. 반대로 탈냉전으로 냉전 시대의 유산인 NATO의 존폐 문제 가 불거진 시점에 일어난 코소보 개입은 역시 인도주의가 명분이기는 했지만 유엔의 승인을 받지 않은 일방적인 무력 개입으로 엄연히 국제법 위반이자 국제관계의 핵심 원리인 주권(sovereignty)을 침해한 행위로 인도주의가 결국은 유럽안보를 이유로 강

14) 소말리아 경우 같은 국제사회의 인도주의 개입 사례로 르완다 내전도 있다. 르완다는 1994년에 다수파인 후투족 출신의 쥐베날 하브야리마나(Juvénal Habyarimana, 1937.3.8 1994.4.6) 대통령이 탄 비행기가 격추돼 사망하자 후투족 극단주의자들이 투치족과 온건 후투족을 무차별 학살하는 사건이 벌어졌다. 이에 유엔의 위임 아래 프랑스가 다국적군을 조직해 정치적 중립을 지키는 조건에서 학살중지와 난민보호를 목적으로 군사적으로 개입했다. 
대국의 군사적 패권을 유지하기 위한 구실에 불과하다는 비판을 자초했다(신의철 2003, 373-375). 비록 유엔이 NATO의 코소보 개입에 대해 사후적으로 '불법이지만 정당하다'(Independent International Commission on Kosovo 2000, 4)는 모호한 평가를 내렸지만, 여하튼 $\mathrm{NATO}$ 의 코소보 개입은 국제사회에 주권이냐 인도주의냐라 는 논란을 제공했다. 이에 따라 주권과 인도주의 개입을 결합할 논리가 필요했고, 그 결과 등장한 것이 '보호책임(responsibility to protect(R2P))' 논리다.

보호책임은 국가주권을 '국가가 자국 내에서 절대적 통치권을 행사할 수 있다'는 전통적인 주권 개념이 아니라 '자국민을 보호할 주된 책임이 해당 국가에 있다'는 의 미로 재정의한다15). 다시 말해, 보호책임은 주권국가가 자국민 보호라는 '일차적 책 임'을 다하지 못할 때 국제사회가 개입할 수 있다는 것(International Commission on Intervention and State Sovereignty 2001; Albright and Williamson 2013)을 의미한다. 2005년 제60차 유엔총회 당시 열렸던 세계정상회의 〈결과문서(Outcome Document)〉를 보면, 보호책임을 적용할 수 있는 상황으로 대량학살(genocide), 전쟁범 죄(war crimes), 인종청소(ethnic cleansing), 그리고 반인도적 범죄(crimes against humanity)로 한정했고, 이에 대해 자국민을 보호할 책임이 있는 주권국가가 보호책임 을 다하지 못하거나 않는 경우에 한해 국제사회가 개입할 수 있다고 규정하고 있다 (General Assembly 2005). 개입 형식은 경고, 제재, 무기금수, 비행금지 등 비군사적 방법뿐만 아니라 최후 수단으로 무력 사용을 전제로 한다. 이런 국제사회의 보호책임 이 첫 적용된 사례가 2011년 아랍의 봄 당시 발생한 리비아 사태다. 유엔안보리는 당시 리비아 정부군이 반정부 시위대를 전투기까지 동원해 학살하자 이를 반인도적 범죄로 규정하고 보호책임을 명분 - 리비아 정부가 주권국가로서 자국민을 보호하지 않고 오히려 학살한다는 이유 - 으로 프랑스를 중심으로 한 다국적군의 군사 개입을 승인했다.

15) 이에 대해서는 http://www.hani.co.kr/arti/opinion/column/626769.html를 볼 것. (검 색일: 2014.11.5) 


\section{2) 유엔평화유지활동}

유엔평화유지활동 역시 넓은 의미에서는 국제사회의 인도주의적 개입 활동에 속한 다. 하지만 유엔평화유지활동이 무기 소지를 허용하지만 사용은 배제한다는 점에서 무력 사용을 전제로 하는 인도주의적 개입과는 다르다. 유엔평화유지활동은 제 2 차 세 계대전 이후인 1948년에 이스라엘이 중동에 국가를 수립하면서 벌어진 제 1 차 중동전 쟁 당시 유엔정전감시단(United Nations Truce Supervision Organisation(UNTSO)) 을 파견한 것이 시초였고, 1956 년에 제 2 차 중동전쟁이 발발했을 때 유엔긴급군 (United Nations Emergency Force(UNEF))을 창설한 것이 유엔평화유지군의 모태가 됐다. 2014년 9월 30일 기준으로 지금까지 총 69차례에 거쳐 평화유지군을 파병했 고, 이 중 16 건 -128 개국 112,696 명 파병(이중 민간인 신분은 16,961 명) - 은 지금 까지도 임무를 수행하고 있다. ${ }^{16)}$ 가장 최근에 파병한 유엔평화유지군은 지난 해 중앙 아프리카공화국에서 강경 이슬람 근본주의 세력인 셀레카(Seleka) 반군이 수도를 장 악하면서 인구의 다수를 점하는 기독교계와 소수인 이슬람계가 충돌해 인종학살에 준 하는 사태가 벌어지자 지난 4월 10일 파병이 결정된 중앙아프리카공화국유엔평화유지 군(United Nations Multidimensional Integrated Stabilisation Mission in the Central African Republic(UNMINUSCA))이다.

냉전 시기에 유엔평화유지활동의 주요 임무는 평화조성과 평화유지였다. 하지만 미·소를 축으로 한 이데올로기 대립으로 유엔평화유지군 파병에 대한 결정권을 갖는 안보리가 파행적으로 운영돼 제 역할을 하지 못했다. 사실, 냉전 시기 국제질서의 유 지 업무는 강대국의 이해관계에 따라 좌우됐다. 하지만 앞서 언급한 대로 탈냉전 국 면에서 대량학살과 인종청소 등 대규모 인권침해를 포함한 전쟁 범죄가 급증하자 유 엔평화유지활동이 새롭게 주목받기 시작했다. 그 이유는 대다수 분쟁이 주권국가 내 부에서 일어나면서 국제사회의 개입 필요성이 증대했지만 주권국가에 대한 외부 개 입은 일종의 주권 침해로 개입의 정당성을 떠나 잠재적으로 국제질서를 혼란에 빠뜨 릴 수 있기 때문이다. 냉전 종식으로 이데올로기적 대립은 어느 정도 불식됐지만, 오

16) 이에 대해서는 http://www.un.org/en/peacekeeping/resources/statistics/factsheet.shtml를 볼 것. (검색일: 2014.11.5) 
히려 이 때문에 국가주권의 원칙이 강조됐다. 그래서 이런 우려를 불식할 수 있는 주체는 회원국들의 집단안전보장체제로서 중립성을 갖는 유엔 밖에 없었다. 이후 유 엔평화유지활동은 평화조성과 평화유지 업무 외에도 예방외교, 분쟁해결, 평화구축, 평화강제로 확대됐다.

물론 유엔평화유지활동에 대한 비판이나 회의적인 시각이 없지는 않다. 최근 들어 중국이나 러시아가 유엔평화유지군 파병에 적극 나서는 편이지만17), 전통적으로 두 국가는 다른 나라의 주권을 침해하는 것으로 비치는 것을 우려해 강대국의 인도주의 적 개입은 물론 유엔 주도의 평화유지활동에 적극적이지 않았다. 오히려 많은 경우 미국이나 영국, 프랑스가 주도하는 인도주의 개입이나 평화유지활동에 거부권을 행 사하거나 기권을 해왔다. 그렇다고 미국이나 영국, 프랑스 등 강대국들이 유엔평화유 지활동에 적극적이란 뜻은 아니다. 앞서 사례에서 다룬 미국의 소말리아 개입, $\mathrm{NATO}$ 의 코소보 개입, 9/11테러 이후 미국의 아프가니스탄 전쟁과 이라크 전쟁, 프 랑스의 말리 내전 개입, 그리고 최근 이라크 북부와 시리아 북동부를 거점으로 테러 를 자행하고 있는 이슬람국가에 대해 미국, 영국, 프랑스가 국제연합전선을 구축해 공습에 나선 데서 알 수 있듯이 이들은 유엔차원의 활동보다 자국의 국익을 앞세우 면서 독자적으로 행동하는 경향이 있다. 이 때문에 유엔평화유지활동에 대한 이들의 지원은 사실 기대만큼 전폭적이지 않다.

이 외에도 유엔평화유지활동을 위해 파병한 군이 활동 중에 범하는 민간인 학살이 라든가 부패, 성추문 사건 등이 종종 보도돼 비판의 도마에 오르곤 한다(Council on Foreign Relations 2013, p. 4). 그리고 현재 유엔평화유지활동이 진행 중인 말리, 수단, 남수단, 콩고민주공화국, 중앙아프리카공화국, 아프가니스탄 등의 경우 과거 한차례 평화유지군을 파병한 적이 있거나 수년째 활동 중임에도 불구하고 사태 해결 의 실마리가 보이지 않으면서 유엔평화유지활동 자체에 대한 회의주의가 만연해 있 다(Council on Foreign Relations 2013, p. 15). 반대로 유엔평화유지군이 활동 중 에 적의 공격을 받아 사망하는 사고가 종종 일어나면서 자위 차원을 넘어 전투 가담

17) 최근에 중국의 유엔평화유지활동에 대한 참여가 부쩍 늘고 있는데 이에 대해서는 http://www.economist.com/news/china/21579495-china-ponders-sending-morecombat-troops-un-peacekeeping-missions-over-there를 참고할 것. (검색일: 2014.11.5) 
에 필요한 무기 사용을 허가해야 하는지 아닌지를 두고 논란이 있기도 하다18). 물론 유엔평화유지활동과 관련한 이런 논란의 중심에는 유엔안보리가 있다. 현재 안보리 는 상임이사국 5 개국과 2 년 임기의 비상임이사국 10 개국을 합해 총 15 개국으로 구성 돼 있다. 하지만 실질적인 권한은 미국, 중국, 영국, 프랑스, 러시아 5 개 상임이사국 이 갖고 있고, 이는 1945년 유엔 설립 이후 지금까지 변함없는 사실이다. 무엇보다 안보리는 회원국 가입 승인, 무력사용 승인 등 유엔의 모든 회원국이 참여하는 최고 의결기구인 총회에 비해 막강한 권한을 가지고 있을 뿐만 아니라 거부권까지 행사한 다. 이 때문에 유엔안보리가 냉전 종식과 세계화 현상 등 국제질서의 변화를 제대로 반영하지 못한다는 비판이 꾸준히 제기되는 등 유엔 개혁 논의의 중심에 서 있다.

\section{2. 법·제도 및 국제개발협력의 측면}

인도주의적 개입과 보호책임, 유엔평화유지활동이 탈냉전 국면에서 분쟁예방이나 분쟁해결을 위한 국제사회의 정치적 또는 군사적 대응 방식이라면, 이와 달리 법·제도 적 맥락에서도 이런 활동이 활발하게 이뤄지고 있다. 탈냉전 국면에서 발생한 여러 분쟁의 경우 앞서 지적한 대로 일부 전투 집단이나 테러 단체가 활동 자금을 마련하 기 위해 혼란을 틈타 약탈, 인질 납치, 밀매, 해외 원조자금 갈취 등 각종 범죄를 자 행하는 등 범죄 집단과 구분되지 않을 정도로 조직화한 범죄를 저지르고 있다. 이들 집단의 경우 자신들의 범죄 행위를 정당화하거나 용이하게 하기 위해 분쟁을 부추기 거나 영속화하는 경우가 많아 분쟁이 또 다른 분쟁을 낳고, 또 국경을 넘어 이웃나라 에도 영향을 미치는 등 악영향이 발생하고 있다. 현재 국제사회는 이런 문제를 방지 하기 위한 방편으로 이들 전투 집단의 자금줄을 차단하기 위해 이들이 주로 노리는 석유, 가스, 광물 자원 등에 대한 불법 거래를 차단하고 투명한 거래를 장려하기 위 해 채취산업투명성기구(Extractive Industry Transparency Initiative(EITI)), 피의 다이아몬드(blood diamond), 즉 분쟁국가 또는 지역에서 생산되는 다이아몬드의 거 래를 규제함으로써 거래 대금이 분쟁 자금으로 사용되는 것을 차단하기 위한 킴벌리

18) 유엔은 평화유지군이 임무 수행 중 사망하거나 부상하는 경우가 많이 발생하자 이를 보호할 목적에서 1994년에 국제연합 요원 및 관련요원의 안전에 관한 협약 (Convention on the Safety of United Nations and Associated Personnel)을 채택 했다. 이에 대해서는 http://www.un.org/law/cod/safety.htm를 참조할 것. (검색일: 2014.11.6) 
프로세스(Kimberley Process), 그리고 킴벌리프로세스와 같은 취지에서 분쟁국가나 지역에서 생산되는 희귀금속 - 텅스턴, 탄탈륨, 주석, 금 등 - 의 투명한 거래를 위 한 분쟁광물규제(Conflict Minerals) 등의 제도를 도입했다. 물론 1945년 유엔 창설 과 동시에 설립된 국제사법재판소나 1948년 채택한 대량학살 범죄 예방 및 처벌에 관 한 협약(Convention on the Prevention and Punishment of the Crime of Genocide) 등 탈냉전 이전에 만들어진 법·제도가 분쟁 자체는 물론이고 분쟁으로 야 기하는 각종 비인도적 범죄를 예방하는 데 여전히 효력을 갖고 있다.

이상의 법·제도적 노력이 선진국 중심으로 이뤄진 것이라면, 반대로 분쟁 및 취약국 주도로 평화구축과 국가건설을 위한 노력이 이뤄지고 있는데, 2011년 12월 부산에서 열린 제4차 원조효과성회의(4th High Level Forum on Aid Effectiveness(HLF4))에 서 채택한 '뉴딜(New Deal)'이 대표적이다. 뉴딜은 분쟁과 개발이 상호 밀접한 관련 을 맺고 있다는 점, 다시 말해 국제개발협력의 맥락에서 분쟁 및 취약국이 분쟁 해결 에 주도적으로 나서고, 이를 통해 국제사회와의 협력을 통해 경제사회개발을 추구한 다는 점에서 분쟁의 평화적 해결을 위한 접근법으로써 상당한 의미가 있다.

뉴딜의 정식 명칭은 '취약국 개입을 위한 뉴딜(New Deal for Engagement in Fragile States)'이다. 취약국이란 분쟁국가와 분쟁 후 국가(post-conflict states)를 포함한다. 그래서 취약국이란 단일 명칭보다 대개 분쟁 및 취약국으로 통칭한다. 일 반적으로 취약성이란 한 국가가 국민의 안전을 담보하지 못할 만큼 권위를 상실한 상태, 국민에게 기본적으로 제공해야 하는 복지를 제공하지 못하는 상태, 정당한 통 치를 하지 못함으로써 국민의 지지를 상실한 상태를 뜻한다(Stewart \& Brown 2009; 권혁주 2010). 분쟁 및 취약국 주도로 뉴딜이 제정된 데에는 국제사회의 최빈 곤 문제 해소를 최우선 목적으로 2001년에 설정된 새천년개발목표(New Millennium Development Goals(이하 MDGs))가 시행에 들어간 직후 이행 상황을 점검하는 과정 에서 분쟁 및 취약국의 이행 실적이 아주 저조하다는 사실이 드러나면서다. 이후 분 쟁 및 취약국에 대한 원조효과성이 의문시 되면서 이를 해소하고자 경제협력개발기구 (Organization for Economic Cooperation and Development(이하 OECD))의 분쟁 및 취약성에 대한 국제네트워크(International Network on Conflict and Fragility(INCAF)) 와 주요 원조공여자들, 그리고 분쟁해결, 평화구축, 국가건설을 위해 자구 노력이 필요 
하다는 $\mathrm{g} 7+19)$ 로 불리는 분쟁 및 취약국 당사자들 간의 '평화구축 및 국가건설에 대 한 국제대화(International Dialogue on Peacebuilding and Statebuilding(IDPS))' 를 통해 뉴딜이 탄생했다. (뉴딜의 구체적인 원칙과 내용은 아래〈표 1〉참조).

〈표 1〉 뉴딜 원칙과 주요 내용

\begin{tabular}{|c|c|}
\hline 원 칙 & 주요 \\
\hline $\begin{array}{c}\text { PSGs } \\
\text { (Peacebuilding and } \\
\text { Statebuilding } \\
\text { Goals) }\end{array}$ & $\begin{array}{l}\text { - 정당성 있는 정치(Legitimate Politics) } \\
\text { - 안보(Security) } \\
\text { - 정의(Justice) } \\
\text { - 경제적 기반(Economic Foundation) } \\
\text { - 조세와 정부 서비스(Revenue \& Services) }\end{array}$ \\
\hline FOCUS & $\begin{array}{l}\text { - F : 취약국 주도 취약성 평가(Fragility Assessment) } \\
\text { - O : 하나의 비전과 계획 수립(One Vision, One Plan) } \\
\text { - } \mathrm{C}: \text { 공여국간 협정(Compact) } \\
\text { - U : PSGs를 통한 모니터링(Using the PSGs to monitor progress) } \\
\text { - S : 정치적 대화 및 리더십 지원 } \\
\quad \text { (Support Political dialogue and leadership) }\end{array}$ \\
\hline TRUST & $\begin{array}{l}\text { - T : 투명성 제고(Transparency) } \\
\text { - R : 위험 분담(Risk Sharing) } \\
\text { - U : 취약국 국가 시스템 활용(Using Country System) } \\
\text { - S : 역량 강화(Strengthen Capacity) } \\
\text { - T : 원조의 적시성 및 예측가능성(Timely and Predictable Aid) }\end{array}$ \\
\hline
\end{tabular}

분쟁과 개발의 맥락에서 뉴딜의 의의라고 한다면, 원조공여자들이 분쟁 및 취약국 의 특수성과 주인의식을 존중하고 분쟁해결과 개발지원을 위해 공동의 원칙과 내용 에 합의했다는 데 있다. 국제개발협력의 맥락에서 분쟁 및 취약국 상황은 일반적인 상황과 분명히 다르다. 이해당사자들 간의 이해관계가 분쟁으로 나타난 상황에서 치 안이 불안한 것은 물론 여러 활동 기반이 개발협력을 제대로 수행 할 수 있는 환경 이 아니다. 이런 상황에서 인도지원이나 개발협력을 위한 무조건적인 외부의 개입은 오히려 분쟁을 더 키우거나 주권침해 등 비판이나 반발에 직면할 수 있다. 2007년에

19) $97+$ 는 IDPS 발족 당시 분쟁 및 취약국의 입장을 대표한 부룬디, 중앙아프리카공화 국, 콩고민주공화국, 라이베리아, 시에라리온, 남수단, 동티모르 7 개국 외에 현재 11 개국이 더 참여해 총 18개국을 회원으로 한다. 현재 뉴딜은 2012년에서 2015년까지 시범기간으로 정하고 아프가니스탄, 중앙아프리카공화국, 콩고민주공화국, 라이베리 아, 시에라리온, 남수단, 동티모르가 시범국가로 자진 참여해 이행하고 있다. 우리나 라는 2012년 유엔총회 기간에 뉴딜을 승인했다. 
OECD의 개발원조위원회(Development Assistance Committee(DAC))는 국제개발협 력에 대한 이런 오해를 불식하고 분쟁 및 취약국에 대한 원조효과성을 제고하기 위 해 '취약국가에 대한 국제사회의 10 가지 모범적인 개입원칙(Principles for Good International Engagement in Fragile States)'(아래〈표 2〉 참조)을 제정했는데, 뉴딜은 이것의 연장선상으로 분쟁 및 취약성을 해소하기 위한 공여자들과 분쟁국 당 사자들 간의 주요 합의로 볼 수 있다.

〈표 2〉 취약국가에 대한 국제사회의 10 가지 모범적인 개입원칙

1. 취약국이 처한 상황을 먼저 살필 것

2. 국제사회의 개입으로 피해가 발생하지 않도록 할 것

3. 국가건설을 중심 목적으로 할 것

4. 분쟁예방을 최우선으로 할 것

5. 정치, 안보, 개발 목표들이 서로 연결돼 있다는 것을 인지할 것

6. 포괄적이고 안정적인 사회를 위한 토대로서 비차별주의를 장려할 것

7. 여러 다른 방식과 맥락으로 현지의 우선순위들을 조정할 것

8. 국제 행위자들 사이에 실질적인 조정 메커니즘에 합의할 것

9. 빨리 행동할 것, 하지만 성공할 수 있도록 충분히 오해 관여할 것

10. 배제되는 사람들(원조 고아)이 없도록 할 것

그런데 뉴딜과 관련해 아쉬운 것은 분쟁과 개발이 밀접한 관련이 있고, 따라서 국 제사회의 평화와 번영을 위해서는 분쟁 해결 못지않게 개발이 중요하다는 인식이 좁 게 잡아도 제 2 차 세계대전 이후 국제관계의 주요 흐름이었음에도 MDGs에서 평화와 안보가 의제로 포함되지 않았다는 것이다. 그 이유는 유엔에서 사실상 막강한 권한 을 행사하면서 평화와 안보를 독자적인 업무 분야로 간주하는 안보리가 개발과 안보 이슈를 결합하는 데 소극적이기 때문이다(Slotin and Elgin-Cossart 2013). 물론 모 든 분쟁 및 취약국이 뉴딜을 지지한다고 할 수는 없다. 뉴딜이 분쟁 및 취약국의 주 인의식을 존중한다고 하지만 분쟁과 개발이 계속 이슈화할 경우 분쟁 및 취약국의 자율성은 상대적으로 줄어들 수밖에 없기 때문이다. 그럼에도 불구하고 늦게나마 MDGs에서 빈곤 해소 및 개발을 위해 분쟁 해결이 중요하다는 인식이 자리 잡고 이 와 관련해 여러 방안이 논의되고 구체적인 원칙이나 방향이 정립된 것, 그리고 2015 
년 종료 시한이 1 년도 채 남지 않은 MDGs의 후속 논의에서 '평화와 안보'가 주요 의 제로 다뤄지고 있는 것은 다행이다.

\section{IV. 나오며: 하나의 논리로 통합돼 가는 “안보' 와 '개발'}

근대국가가 출현한 이후 탈냉전 이전까지 국제분쟁의 주요 주체는 폭력을 합법적 으로 독점한 국가였다. 하지만 냉전이 종식한 뒤 세계화와 더불어 상대적으로 국가 가 후퇴하면서 소위 내전으로 불리는 국가 내 분쟁이 크게 증가했다. 국가 내 분쟁 은 분쟁 당사자들이 기존에 국가가 독점했던 폭력을 (재)사유화하고, 국민의 안전을 담보했던 국가가 오히려 국민의 안전을 해치는 당사자가 됐으며, 이로 인해 과거 분 쟁 상황에서 상대적으로 엄격히 구분됐던 전투원과 민간인의 구분이 다시 모호해졌 다. 이 결과 최근에 일어나는 분쟁에서는 전투원보다 민간인 사망자가 압도적으로 많다. 그리고 국가 내 분쟁이 인종이나 종족, 언어와 문화, 종교가 복합적으로 결부 돼 일어나면서 인종청소 같은 대량학살, 난민 발생, 그리고 인권침해 등 대규모 인도 주의 문제를 초래해 국제사회를 경악케 하고 있다. 여기에 2001년 9/11 테러 이후 테러리즘이 가세하면서 분쟁이 더욱 확산돼 국경을 넘어 국제사회 전체를 공포로 몰 아넣고 있고, 그 결과 분쟁이 분쟁을 낳는 분쟁의 악순환을 초래했다. 한 통계에 따 르면, 현재 분쟁 및 취약국에 살고 있는 인구는 약 15 억 명이다. 이는 브라질, 중국, 인도를 제외한 개발도상국 전체 인구의 약 $47 \%$ 에 해당한다. 그리고 분쟁 및 취약국 의 $70 \%$ 가 1989 년 냉전 종식 이후 분쟁에 빠졌는데, 이 가운데 $40 \%$ 정도는 분쟁에서 벗어난 지 10 년 이내에 다시 분쟁이 재발했다. ${ }^{20)}$

이런 분쟁의 악순환은 국제정치적 맥락과 국제개발협력의 맥락에서 각각 중요한 함의를 갖는다. 우선, 국제정치적 맥락에서 갖는 함의는 현재 이뤄지고 있는 분쟁에 대한 국제사회의 대응이 올바른가 하는 문제와 관련이 있다. 현대 분쟁이 합법적 폭 력 독점 능력을 상실한 국가를 포함한 '비국가' 행위자들이 병렬적 대결 구도에서 벌 어지고 있음에도 불구하고 국제사회의 대응 방식은 과거 국가 간 전쟁에 대한 대응

20) 이에 대해서는 http://www.newdeal4peace.org/wp-content/themes/newdeal/docs/new-deal-forengagement-in-fragile-states-en.pdf를 참조 할 것. (검색일: 2014.11.10) 
방식에서 크게 벗어나지 않았다. 유엔안보리의 분쟁 당사자들에 대한 해결 권고안 및 결의안 채택, 정치·경제적 제재나 압박, 유엔평화유지군 파병, 또는 강대국 중심의 일방적 개입 - 강대국 일방의 개입 또는 NATO나 동맹국가들 간의 제휴를 통한 개 입 - 이 주를 이룬다. 이런 대응 방식은 종래에 국가안보와 국민안보를 최우선으로 했던 강대국 중심의 국가 행위자가 테러단체들이나 조직화한 범죄단체들 같은 비국 가 행위자들이 벌이는 분쟁을 중재 및 해결하기 위해 개입하는 방식인데 몇 가지 한 계나 문제점이 있다.

첫째, 비대칭적 전력이라는 측면에서 국가 행위자가 비국가 행위자들보다 압도적 으로 우위에 있음에도 전술적으로 비국가 행위자들을 막는데 크게 효과적이지 않다. 다시 말해, 비국가 행위자들의 게릴라식 전술이나 테러에 대한 국가 행위자들의 화 력 위주의 대응 방식이 효과를 내지 못하는 것이다. 오히려 분쟁이나 혼란을 더욱 부추겨 분쟁을 인접한 이웃이나 지역으로 확산하는 역효과를 초래하기도 한다. 최근 에 프랜차이즈화하고 네트워크화 한 테러리즘이 이를 잘 보여준다(Riedel 2012; 이 현 2014). 2001년 9/11 테러 이후 미국이 알카에다 척결을 내걸고 개입한 대테러리 즘 - 아프가니스탄 전쟁과 이라크 침공 - 은 오히려 테러 세력의 세계적 확산을 부 추기고 있다. 둘째, 현대 분쟁에서 전투원과 민간인의 구분이 모호해지면서 민간인 사망자가 늘고 있는데, 이는 분쟁당사자들에 의한 민간인 학살도 원인이지만 외부에 서 분쟁을 해결하기 위해 개입한 군대 역시 전투원과 민간인의 구분이 모호한 상황 에서 무차별적으로 대응한 결과다. 미국이 이라크와 아프가니스탄에서 대대적으로 벌인 대테러리즘 전쟁은 전투원보다 더 많은 민간인 사망자를 낳았다. ${ }^{21)}$ 이 때문에 미국의 대테러리즘 일환으로 13 년째 전쟁을 치르고 있는 아프가니스탄에서는 탈레반 의 압제가 더 낫다는 웃지 못 할 이야기도 나온다. 특히 미국은 2008년 금융위기 이 후 천문학적인 재정적자로 인해 대테러리즘 수단의 하나로 무인기, 즉 드론(drone)을 도입했는데 드론의 경우 통신 감청이나 첩보 위성을 통해 수집한 정보를 바탕으로

21) 2003년 미국이 대량살상무기를 구실로 시작한 이라크 전쟁으로 인한 사망자는 2013 년 말 기준 - 비록 2011년 말 완전 철군하기는 했지만 지금도 계속 분쟁이 지속되고 있다는 점을 감안해 - 으로 20 만 명을 넘는다. 이중 민간인 사망자는 13 만 명이 넘 는 것으로 추산한다. 이에 대해서는 https://www.iraqbodycount.org/analysis/reference/announcements/5/를 볼 것. (검 색일: 2014.11.7) 
테러 집단의 거점이나 주요 테러리스트들을 폭격하기 때문에 오인 공격으로 인한 민 간인 사망자가 다수 발생하고 있다. 마지막은 이런 이유로 국가의 합법적 폭력 독점 및 사용에 대한 정당성이 크게 훼손됐고, 또 국가가 국민의 안전을 담보하기보다는 비국가 행위자들과 마찬가지로 국민의 안전을 되레 헤치면서 국가에 대한 불신이 증 폭했다.

국제개발협력의 맥락에서 분쟁의 악순환은 '분쟁과 개발'이라는 측면에서 중요한 함의를 갖는다. 탈냉전 국면에서 벌어진 분쟁은 분쟁 당사국의 국가 기능을 마비시 켰다. 극단적으로 냉전 시기에는 존재하지 않았던 '국가실패(state failure)' 또는 '실 패한 국가(failed states)'라는 용어마저 등장했다. 무엇보다 인권침해, 난민발생, 빈 곤, 차별, 불평등, 부정부패 등 사회적 부조리가 분쟁 상황과 결합하면서 애초 분쟁 의 원인과 결과를 구분하는 것이 모호해졌고, 이로 인해 '안보 논리'와 '개발 논리'가 밀접하게 결합해 가고 있다. 물론 어느 한 시점에서 어느 한 원인이 분쟁을 야기하 고, 분쟁이 다시 원인을 가중하는 현상을 찾아낼 수는 있을 것이다. 당연히 이런 경 우에는 분쟁의 원인을 사전에 감지하거나 찾아내 예방하려는 노력이 중요하다. 그러 나 이미 분쟁이 진행 중이고 장기화하는 상황에서는 국가 기능의 약화나 마비로 인 도주의 상황이 악화할 수밖에 없고, 더구나 최근 분쟁의 경우 누차 강조한 대로 일 부 전투 집단이 활동 자금을 마련하기 위해 공포를 조장하고 이 틈을 타 조직화한 범죄를 저지르는 상황에서는 분쟁 자체와 분쟁 원인을 이분법적으로 나누는 것이 무 의미해 보인다. 즉, 이런 상황에서는 분쟁이 분쟁의 원인이자 결과로 작용함으로써 분쟁이 영속화한다. 이런 분쟁을 해결하기 위해서는 분쟁이라는 '두려움으로부터의 자유(freedom from fear)'를 보장하는 '안보 논리’와 분쟁의 원인이자 결과일 수 있 는 '결핍의 자유(freedom from want)'를 충족하는 '개발 논리'가 '동시적으로' 이뤄 져야 할 필요가 있다. 다시 말해, 선(先) 분쟁 해결, 후(後) 개발 논리가 더 이상 타 당하지 않다는 뜻이다.

그런데 국제정치적 맥락에서나 국제개발협력의 맥락에서 지금의 국제질서를 돌아 보면 평화의 논리와 개발의 논리가 여전히 상충하는 것처럼 보인다. 한쪽에서는 평 화라는 이름으로 분쟁을 계속 유발하거나 부추기고 있고, 다른 한쪽에서는 조금이나 마 분쟁 해결, 평화 달성에 도움이 될 수 있지 않을까라는 기대에서 개발지원에 힘 
을 쏟고 있다. 이 때문에 분쟁 해결과 개발 지원이 서로 별개로 간주되거나 분쟁 해 결이 먼저 돼야 개발 지원이 가능하다는 인과 논리에 빠진 것처럼 보이는데, 개발지 원도 넓은 의미에서 평화를 달성하기 위한 하나의 수단이라고 할 때 이런 인식은 현 실적이지 않다. 여하튼 두 개의 지향점이 같다고 할 때 생각해봐야 할 것은 어느 것 이 더 안전하고, 평화롭고, 더 인류를 위한 방법인가 하는 것이다. 이는 평화가 번영 을 가져올 수 있다는 생각, 개발이 평화를 가져올 수 있다는 인과적인 논리가 아닌 평화와 개발이 동시적으로 같이 가야한다는 뜻이다. 특히 분쟁국가의 개발협력은 이 런 식의 인식과 접근이 더욱 중요하지 않을까 싶다.

제I장

개
발
협
력
이
슈

제I장

제 III장

제 $\mathrm{IV}$ 장 


\section{참고문헌}

\section{-국내문헌}

권혁주. 2010. "취약국가의 이해: INCAF와 국제협력 기구의 논의를 중심으로". 『국제개발협력』(제3호). 성남시: 한국국제협력단, pp. 46-65.

김재천. 2008. “클라우제비츠이론으로 본 '테러와의 전쟁': 독일 통일전쟁과 이 라크/아프가니스탄 전쟁 비교연구”. 한국국제정치학회 2008 건 국 60주년 기념 공동학술회의 자유공모패널 2, pp. 259-286.

이현. 2014. "테러리즘과 국제개발협력: '분쟁과 개발'의 맥락으로 본 테러리즘", 『국제개발협력』(제 3 호). 성남시: 한국국제협력단, pp. 177-194. 최의철. 2003. "국제사회의 인도적 개입: 이론과 실제”. 『통일정책연구』 $12(2)$. pp. 369-404.

\section{-국외문헌}

Albright, Madeleine K. and Williamson, Richard S. 2013. The United States and R2P: From Words to Action. Washington, DC: United States Institute of Peace.

Clausewitz, Carl von. 1832. On War. trans, and ed. Michael Howard and Peter Paret. New York: Knopf.

Collier, Paul. 2007. Bottom Billion. Oxford: Oxford University Press.

Council on Foreign Relations. 2013. "The Global Regime for Armed Conflict". Issue Brief(June 19, 2013).

http://www. cfr. org/peacekeeping/global-regime-armed-co nflict/p24180. (검색일: 2014.11.10)

Creveld, Martin van. 1991. The Transformation of War. New York: The Free Press.

Fleming, Colin M. 2009. "New or Old Wars? Debating a Clausewitzian Future". The Journal of Strategic Studies Vol. 32 No. 2. pp. $213-241$. 
Fukuyama, Francis. 1992. The End of History and the Last Man. New Yoke: The Free Press

General Assembly. 2005. "2005 World Summit Outcome(A/RES/60/1)".

International Crisis Group. 2014(a). "Ukraine: Running out of Time". Europe Report No 231. Belgium: Brussels.

International Crisis Group. 2014(b). "Old Scores and New Grudges: Evolving Sino-Japanese Tensions". Asia Report No 258. Belgium: Brussels.

Kaldor, Mary. 2007. New \& Old War: Organized Violence in a Global Era(2nd Edition). Cambridge: Polity Press.

Keegan, John. 1991. A History of Warfare. New York: Vintage.

Kerr, Pauline. 2010. "Human Security". Alan Collins ed. Contemporary Security Studies(2nd Edition). Oxford: Oxford University Press. pp. 121-135.

Lind, William S. 2004. "Understanding Fourth Generation War". Military Review Vol. 83 No. 5(Sept.-Oct.). pp. 12-16.

Riedel, Bruce. 2012. "Al Qaeda 3.0: Terrorism's Emergent New Power Bases". The Daily Beast.

http://www. thedailybeast. com/articles/2012/12/03/al-qaed a-3-0-terrorism-s-emergent-new-power-bases.html. (검 색일: 2014.11.10)

Slotin, Jenna and Elgin-Cossart, Molly. 2013. Why Wold Peace be Controversial at the United Nations? Negotiations Toward a Post-2015 Development Framework. New York: Center on International Cooperation.

Stewart, Frances and Brown, Graham. 2009. "Fragile States". Crise Working paper No. 51. Oxford: Centre for Research On Inequality, Human Security and Ethnicity.

The Independent International Commssion on Kosovo. 2000. The Kosovo Report: Conflict, International Response, Lessons Learned. Oxford: Oxford University Press. 
The International Commission on Intervention and State Sovereignty. 2001. The Responsibility to Protect. Ottawa: International Development Research Centre.

United Nations Development Programme. 1994. Human Development Report 1994. Oxford: Oxford University Press.

World Economic Forum. 2014. Global Risks 2014(9th Edition). Geneva: World Economic Forum. 